\title{
A ORGANIZAÇÃO CORDIAL ENSAIO DE CULTURA ORGANIZACIONAL DO GRÊMIO GAVIÕES DA FIEL
}

$\star$ André Lucirton Costa

7951002@lepi.fgusp.br

\section{PALAVRAS-CHAVE:}

cultura organizacional, futebol, organizações brasileiras, cultura brasileira, torcida organizada.

\section{KEY WORDS:}

organizational culture, soccer, Brazilian organization, Brazilian culture, organized rooters.

\section{$\star$ Professor da ESPM e Coordenador das Faculdades Tibiriçá.}

(rae@eaesp.fgvsp.br) Assinatura E-mail 
Alguns traços do comportamento cultural brasileiro podem ser encontrados na Torcida Organizada Gaviões da Fiel, tendo aspectos da cultura brasileira como parâmetro.

Some traces of Brazilian cultural behavior can be found in the Torcida Organizada Gaviões da Fiel, taking some aspects of Brazilian culture as a parameter.

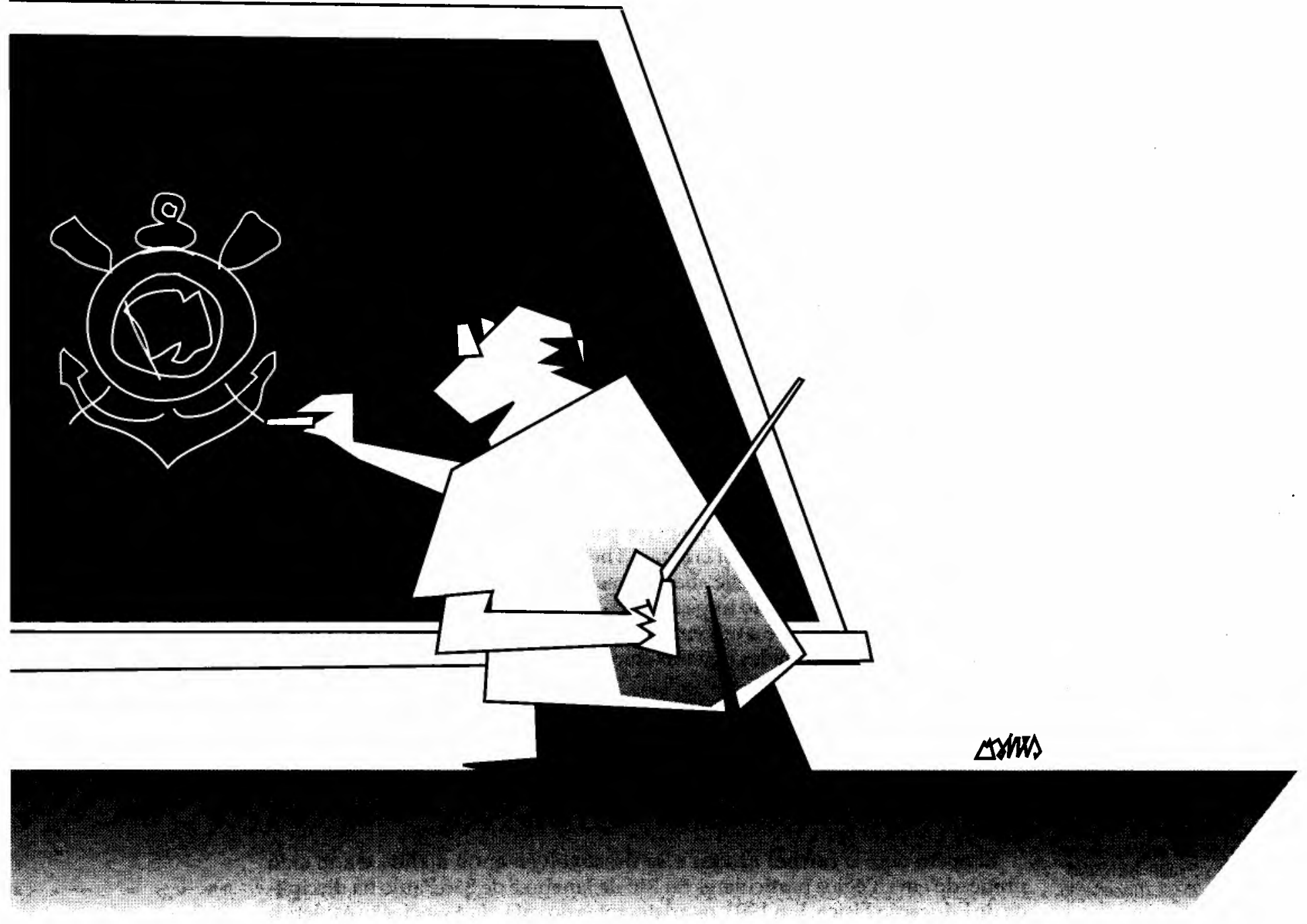

"O vosso mau amor de vós mesmos vos faz do isolamento um cativeiro."

(Nietzsche) 
1. Nasceu da mesma matriz esportiva que o rugby, do qual se separou por divergências sobre as regras entre os praticantes. Ver maiores detalhes sobre a história do futebol (inclusive suas variantes mais antigas e violentas, presentes na história da humanidade) em SANTOS, Luiz T. Futebol empresa e a democracia corinthiana: uma administração que de udribling na crise. Şāo Paulo: UNICAMP, nov.1990. p. 25-32. (Dissertação de Mestrado)

2. CALDAS, Waldenyr. Aspectos sociopolíticos do futebol brasileiro. Revista da USP, São PauIo, n. 22, p. 41-9, Jun./Ago. 1994.

3. Idem, ibidem. mpressiona a escassez de estudos sociocomportamentais envolvendo o tema "futebol" no Brasil, dada a óbvia importância social deste esporte no país. Abordar organizaçóes notoriamente brasileiras, tendo como parâmetros aspectos da cultura nacional, reveste-se de importância estratégica na elaboração e consolidação de um modelo brasileiro de gestão. É nesse contexto que este trabalho se insere. Procura analisar, com um estudo de caso, aspectos da cultura brasileira na organização denominada Grêmio Gavióes da Fiel - Torcida Uniformizada em Prol do Corinthians, com ampla participação popular, que extravasou as fronteiras futebolísticas. Competindo, em São Paulo, como bloco carnavalesco, sagrou-se campeão doze vezes e como escola de samba no grupo principal venceu uma vez.

\section{O FUTEBOL}

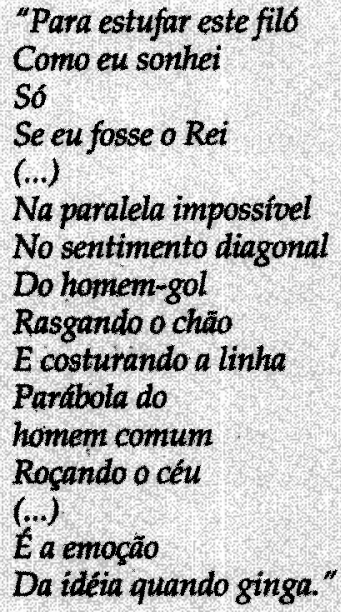

(O Futebol. Música e letra de Chico Buarque de Holanda.)

No Brasil, usa-se comumente a afirmação "sobre mulher, futebol e religião não se dicute" quando se quer evitar brigas ou desavenças. O futebol, tal qual a mulher, é sinônimo de paixão. Uma paixão que, para o brasileiro comum, não pode ser explicada verbalmente: ela é sentida, está no universo das "coisas" relacionadas ao espírito.

$O$ formato deste esporte que desperta paixão no brasileiro foi definido em 1863, na Inglaterra ${ }^{1}$, quando foi criada a The Football Association . O futebol, tal como é conhecido hoje, teve suas regras definitivamente estruturadas em 1924 com o conceito da lei do impedimento.

Um dado significativo é a origem elitizada deste esporte, criado por alunos de tradicionais universidades inglesas como alternativa para a esgrima, o tiro e a equitação.

No Brasil, "só tomaríamos contato com o football em 1894. Charles W. Miller, brasileiro filho de ingleses, estudava em Londres. Ao voltar para o Brasil (São Paulo), sua bagagem trouxe uma bola de futebol (...). O primeiro 'grande' jogo foi realizado em São Paulo, em 1899. Os adversários eram times de funcionários da empresa Nobiling, contra os ingleses da Companhia de Gás, da São Paulo Railway e do Banco de Londres" 2 .

Também aqui o futebol nasceu e se desenvolveu entre a elite, tendo sido praticado em colégios particulares do Rio de Janeiro e de São Paulo na disciplina de Educação Física. Em 1903, os aristocratas do café, da Associação Athletica Ponte Preta, formaram o que seria o primeiro time organizado do Brasil. A partir daí, esse esporte difundiu-se para as camadas populares, como observado por Caldas ${ }^{3}$ ao narrar a história do The Bangu Athletic Club, criado por funcionários ingleses da Cia. Progresso: "Localizada na periferia distante, num bairro operário, a Cia. Progresso iria estimular o futebol entre seus executivos como forma de lazer. Mas, como formar dois times para competir, se o número de funcionários mais 
graduados e interessados neste esporte não chegava a tanto? A alternativa seria aceitar os operários para completar as duas esquadras. O critério de escolha, para isto, obedeceria algumas exigências administrativas na empresa, tais como: o desempenho profissional, o tempo de serviço e o comportamento pessoal. Surgiria assim o primeiro clube de futebol no Brasil não inteiramente elitizado".

É interessante observar que esse fenômeno não foi singular. Antunes ${ }^{4}$ afirma que muitas empresas, como Votorantim e Regoli e Cia., criaram seus clubes. As fábricas passaram a incentivar e financiar clubes de futebol amador formados pelos próprios trabalhadores. Elas os patrocinavam mas mantinham o controle financeiro e administrativo. $\mathrm{O}$ interesse das empresas era óbvio: além dos aspectos promocionais, conseguiam promover uma identificação clube-empresa, suscitando a crença de que jogadores, trabalhadores $\mathbf{e}$ patrões faziam parte de uma grande família. A

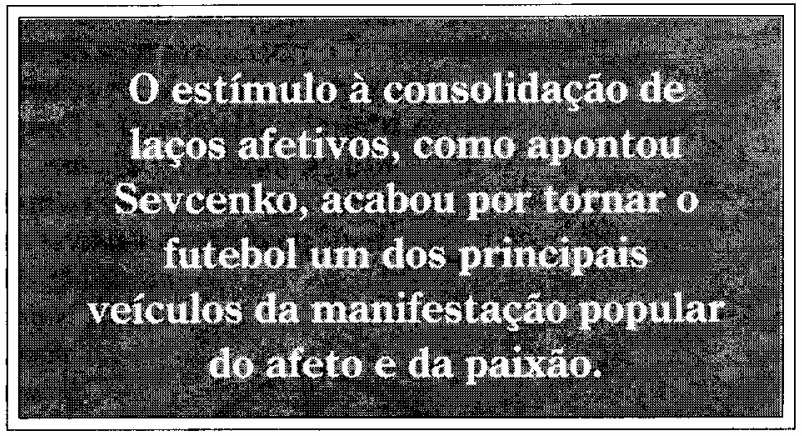
vitória no futebol aumentaria o orgulho do trabalhador pelo clube e pela empresa do qual fazia parte e o sentimento de integração poderia, assim, reduzir os conflitos no local de trabalho.

Outras organizações que prosperaram na popularização do futebol foram os clubes de várzea, mais espontâneos que seus pares fabris. "As margens dos rios foram transformadas em campos de futebol e passaram a funcionar como ponto de encontro e divertimento de trabalhadores e suas familias. A expansão dos times de várzea e a incorporação de seus jogadores aos clubes profissionais foram etapas importantes na difusão do futebol no Brasil"5.

Mas a expansão do futebol das elites para o povo tem uma história particular. Nicolau Sevcenk $o^{6}$ afirma que é um esporte moderno, difundido a partir da expansão das cidades durante a Revolução Industrial, quando ocorreram gigantescas ondas migratórias. Nas novas metrópoles as pessoas, vindas de diferentes partes do país ou do mundo, não tinham raiz ou tradição. Na busca de laços afetivos, emocionais, de identidade coletiva que substituíssem os antigos laços de parentesco, parcelas significativas da população foram "dragadas para a paixão futebolística que irmana estranhos, faz comungarem ideais, objetivos e sonhos, consolida gigantescas familias vestindo as mesmas cores". Continua o autor: "Ofutebol se presta maravilhosamente a consolidar vinculos de identidade plenos de carga afetiva ${ }^{\prime \prime}$.

Ainda segundo Sevcenko, o futebol estabelece esses laços afetivos pela singularidade de algumas de suas características. Em primeiro lugar, porque é um esporte de equipe, implicando grande número de funções dentro de campo, que, tal como na convivência em uma coletividade, são bem desempenhadas somente se se harmonizarem num conjunto coordenado. Em segundo, porque este é um esporte praticado com os pés - e isto também o distingue dos demais - , produzindo movimentos imprecisos e mais lentos, o que amplia o papel do acaso e do senso de oportunidade. Essas duas características permitem que o expectador seja ao mesmo tempo ator: em razão do acaso e imprecisão nos movimentos dos jogadores e da necessidade de coordenação coletiva do conjunto, a sua "torcida" pode influir no resultado da partida (quem já foi a alguma final de campeonato sabe disto).

Além disso, um outro fator pode ampliar a identidade: "essa preponderância do elã coletivo e do efeito coreográfico, assim como a ênfase sobre a habilidade com os pés e o uso malicioso dos movimentos do corpo, diminui ou compensa as exigências do destaque físico (...); o comum, mesmo sendo jogador de futebol, é ter porte que corresponda ao padrão físico médio da sociedade a que ele pertence. O que favorece ainda mais tanto a identificação do torcedor com o jogador, como a disposição de qualquer pessoa ${ }^{8}$ (...) de praticar o esporte ${ }^{g \prime \prime}$.

Quanto às manifestações de identidade coletiva nesse esporte, alguns autores insistem em argumentar que a carência afetiva criada na passagem para a sociedade industrial fez com que a classe dominante, para atenuar o abismo

4. ANTUNES, F. M. R. F. 0 futebol nas tábricas. Revista da USP, São Paulo, n. 22, p. 102-9, jun./ ago. 1994.

5. Idem, ibidem.

6. SEVCENKO, N. Futebol, metrópoles e desatinos. Revista da USP, São Paulo, n. 22, p. 30-7, jun./ago. 1994.

\section{Idem, ibidem.}

8. Neste sentido, o Brasil é ainda mais pródigo em demonstrar esta falta de padrão físico. 0 folclore futebolístico narra uma passagem em que 0 jogador Nilton Santos, vendo a primeira apresentação de Garrincha, chegou a comentar, em tom de indignação, que estavam aceitando até aleijado para jogar no Botafogo.

9. SEVCENKO, N. Op. cit., p. 30-7. 
social criado pelo novo modelo econômico, usasse o futebol como uma espécie de "carta de penhor do populismo", buscando, com isso, afagar sua "dívida afetiva".

No Brasil, a manipulação do futebol pela elite dirigente (os "cartolas" e os políticos) fez com que a esquerda brasileira, por muito tempo, rotulasse este esporte como "ópio do povo", demostrando, aí, uma visão limitada de importantes aspectos da cultura popular brasileira.

Como a outra face de uma moeda, o futebol atuou ludicamente também em outras formas de representação social menos "alienantes", como pondera DaMatta": "Habituada a jogar e não a competir, a sociedade brasileira, constituída de favores, hierarquia, clientes, e ainda repleta de ranços escravocratas, reagia ambiguamente ao futebol. Esse estranho jogo que, dando ênfase ao desempenho, democraticamente produzia ganhadores e perdedores (...). Desse modo, foi certamente esta humilde atividade, este jogo inventado para divertir e disciplinar que, no Brasil, transformou-se no primeiro professor de democracia e de igualdade. Pois não foi através do parlamento que o povo aprendeu a respeitar as leis, mas assistindo ao futebol".

Ainda segundo esse autor, "embora o futebol seja uma atividade moderna, um espetáculo pago, produzido e realizado por profissionais da indústria cultural, dentro dos mais extremados objetivos capitalistas ou burgueses, ele, não obstante, também orquestra componentes cívicos básicos, identidades sociais importantes, valores culturais profundos e gostos individuais singulares. No fundo, o futebol prova que se podem acasalar valores culturais locais, nascidos de uma visão de mundo tradicional e particularista, com uma lógica moderna e universalista (...). Tudo indica que o esporte tem um lado instrumental ou prático que permite 'fazer' coisas e promover riqueza; mas ele também tem um enorme eixo expressivo elou simbólico que apenas diz e, com os rituais, revela quem somos".

Nossa crônica esportiva, apresenta-nos ainda outros questionamentos sobre o futebol como este, de Nelson Rodrigues, sobre a seleção brasileira: "Por que o Brasil não gosta do Brasil e por que nos falta um mínimo de auto-estima? E a pergunta que me faço sem achar resposta

(...). Simplesmente o Brasil não existe para nossas elites (...). Há um momento, todavia, em que todos se lembram do Brasil, em que 90 milhões de brasileiros descobrem o Brasil. Aí está o milagre do escrete (...). É, então, um pretexto, uma razão, para auto-estima. E cada vitória compensa o povo de velhas frustraçōes, jamais cicatrizadas" 11 .

O futebol revela, sem dúvida, muitas das características da cultura brasilei$\mathrm{ra}^{12}$, dentre as quais pode ser destacada a tendência à "carnavalização", representada pelo fato de ele possibilitar uma troca de papéis e da hierarquia neste esporte, os heróis são, predominantemente, negros e mulatos. O malan-

10. DaMATTA, Roberto. A antropologia do óbvio. Revista da USP, São Paulo, n. 22, p. 10-7, jun./ago. 1994.

11. RODRIGUES, Nelson. Entendido, salvo do ridículo. In: $\dot{A}$ sombra das chuteiras imortais: crônicas de futebol. Seleção de Rui Castro. Companhia das Letras. $5^{a}$ reimpressão. 1993. (Publicada em 0 Globo, 10 jun.1970).

12. Esta representação e dramatização pode ser vista em DaMATTA. A antropologia do óbvio... Op. cit., p. 10-7. dro também se faz presente através do jogo de cintura e do típico jogo de pernas do futebol brasileiro que tanto desconcerta o adversário (aqui o malandro e o herói se confundem).

O futebol também contribui para a idéia de coletividade exclusiva, como a casa ou a família, numa dimensão moderna onde, de um lado, se tem um sentido de coletividade (a casa, o time) e, de outro, indivíduos com normas universais (a rua, as regras do futebol).

Mas o futebol não é só revelação, é também dramatização (ou, como disse Chico Buarque, "uma parábola"). O brasileiro se vê no futebol, coloca-se no papel do jogador e aprende nesse papel. A prende liçóes de democracia, de igualdade, de respeito às regras. Descobre a experiência da vitória, do sucesso, onde vencedores e perdedores se alternam sistematicamente: "Aprende-se, pois, que a alternância na glória é a glória da alternância - base da igualdade e da justiça moderna (...). Além disso, o futebol instituiu abertamente a malandragem como arte de sobrevi- 
vência e o jogo de cintura como estilo nacional. Mas sem excluir a capacidade de jogar com força" ${ }^{\prime \prime}$.

Futebol ensina, como ilustra mais um trecho de Nelson Rodrigues. "Dizem que o Brasil tem analfabetos demais. E, no entanto, vejam vocês: a vitória final, na copa da Suécia, operou um milagre. Se analfabetos existiam, sumiram na vertigem do triunfo. A partir do momento em que o rei Gustavo da Suécia foi apertar as mãos dos Pelés, dos Didis, todo mundo aqui sofreu uma alfabetização súbita. Sujeitos que não sabiam se gato escreve com $x$ iam ler a vitória no jornal (...). Amigos, nunca se leu e, digo mais, nunca se releu tanto no Brasil" 14 .

Nascido no coração da sociedade industrial, um jogo com regras rígidas, porém imprevisível; sujeito à coordenação de equipe, mas possibilitando "jogadas" individuais. Sem um biotipo definido, facilitando profunda identificação do herói com o torcedor, o futebol ganhou terreno e se consolidou como o esporte mais praticado no mundo. E o brasileiro passou a ter a fama de ser aquele que melhor joga este complexo esporte porque, inequivocadamente, conseguiu colocar a marca da sua cultura num estilo leve, liberto, individual e coletivo ao mesmo tempo, com flexibilidade e criatividade.

O estímulo à consolidação de laços afetivos, como apontou Sevcenko, acabou por tornar o futebol um dos principais veículos da manifestação popular do afeto e da paixão. O homem cordial, protótipo do brasileiro, e fruto da contradição da sociedade patriarcal com o capitalismo moderno - definição clássica de Sérgio B. de Holanda - , encontrou no futebol a base ideal para expressar a sua emoção.

O povo brasileiro incorporou a um esporte importado características de seu perfil cultural, dando-lhe novo dinamismo. O seu futebol tornou-se sucessivamente campeão, numa demonstração clara da sua capacidade de assimilação e de transformação cultural.

As vitórias da seleção de futebol brasileira talvez sejam, ainda hoje, a melhor resposta "prática" às teorias que usam a raça, o clima e a geografia para explicar as diferenças de desenvolvimento entre os povos, teorias estas que parecem ganhar alento novamente no Primeiro Mundo. É delicioso imaginar os problemas que os Pelés ${ }^{15}$, os Didis, os Zicos e os Manés de pernas tortas trouxeram e trazem ainda a essas teorias racistas. $O$ povo brasileiro certamente sabe que tem do que se orgulhar.

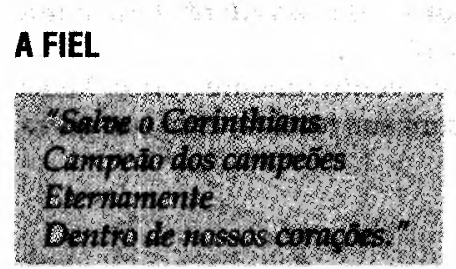

(Trecho do hino do Sport Club Corinthians Paulista.)

Segundo Luís Tolosa Santos"16, "a história do Corinthians começa com (...) quatro funcionários da Companhia de Estrada de Ferro 'São Paulo Railuqy' que residiam no bairro do Bom Retiro, Sāo Paulo. Sempre se reuniam na rua José Paulino, para comentar as habilidades dos jogadores ingleses do Corinthians Team, que por aqui havia passado, em 1910...".

Continua o autor: "O Corinthians iniciou-se como clube de futebol jogando na várzea menor. Muito embora se começasse a evidenciar nele todas as qualidades que mais tarde lhe iriam ornar a "personalidade", teve muito que lutar nos seus primeiros anos (...). Narram os historiadores que o Corinthians era conhecido como o 'galo brigador' do Bom Retiro. Tendo na base a vontade de ser um grande clube, o Corinthians foi se fazendo popular. Segundo sua diretoria, para ser corinthiano era necessário ser operário, ser trabalhador do pesado. Era essa a credencial de sua ficha de sindicância. Isso fez com que, desde o início, passasse a contar com a simpatia popular, sem privilégios, sem preconceito de cor, $e$, so-
13. Idem, ibidem.

14. RODRIGUES, Nelsọn. É chato ser brasileiro! In: $\dot{A}$ sombra das chuteiras... Op. cit. (Publicado em Manchete Esportiva, 12-07-1958)

15. Ressalte-se que não é um ariano ou um branco europeu 0 atleta do século, mas um negro, brasileiro, que conseguiu reunir 0 vigor físico, a habilidade com os pés, o raciocino rápido e a visão de jogo e, por que não, a malícia.

16. SANTOS, Luiz T. Op. cit. 
17. Essa característica de sofredor foi marca registrada do corinthiano durante as décadas de 60 e 70 , quando o time ficou 24 anos sem ganhar um campeonato (como se o povo não ganhasse nenhuma disputa nesta época). Houve até uma famosa marchinha carnavalesca que falava do torcedor sofredor: "Doutor, eu não me engano, meu coração é corinthiano!", (M. Ferreira, R. Amaral e G. Júnior).

18. TOLEDO, L. H. Transgressão e violência entre os torcedores de futebol. Revista da USP, São Paulo, n. 22, p. 93-101, jun./ago. 1994.

19. $\mathrm{Na}$ época presidente do Corinthians (hoje deputado federal) bretudo, sem fingir ser o que não era (...). No primeiro Campeonato Paulista, a participação do Corinthians não foi das melhores: terceiro lugar. Mas no ano seguinte (1914), a grande torcida, quase toda de operários, via seu time ser campeão invicto da liga".

Desde a sua fundação, o Corinthians acumulou inúmeros títulos e cresceu. Criou-se um grande clube com administração profissional, dirigido por um conselho e diretoria voluntárias (não-remuneradas), com inúmeras atividades esportivas e sociais. O Sport Club Corinthians Paulista cresceu e se burocratizou. Contudo, seu espírito inicial - de time popular, sem privilégios - mantém-se vivo dentro do torcedor como comprovam as declaraçōes a seguir, coletadas em entrevistas realizadas na sede do Gaviões da Fiel e em jogos do time durante o período abrilmaio de 1995: "Sou corinthiano desde pequeno, né, porque corinthiano vem do povo, né meu, do trabalhador, vem do povo (...) por isso que sou corinthiano." (Renato, torcedor entrevistado no jogo Corinthians x Grêmio, em 14-061995).

Um pouco mais enfático foi o Pancho (diretor do Gavióes), quando respondeu à pergunta de como ele imaginava o Corinthians: "Quando falam do Corinthians para mim, o que eu imagino? Eu imagino o povo, eu sou bem brasileiro, tenho o sangue bem brasileiro. O Corinthians para mim é o povo, aquele povo bem sofrido, aquele povo que às vezes deixa de dar o leite em casa para pagar o ingresso, é aquele amor, é aquela paixão, é aquela coisa que realmente o cara se entrega (...). O corinthiano é o mais apegado. Tá lá, aos 44 minutos e o time perdendo e ele tá lá torcendo (...), ai tá a demonstração de paixāo (...) a torcida do Corinthians é o povão".

Em todas as entrevistas realizadas, a tônica era uma só: o Corinthians é o time do povo, do povo sofredor.

Os "gritos de guerra" também demonstram essa identificação dos corinthianos. À provocação de palmeirenses "Ara, ara, ara, silêncio na favela!", a resposta vem rápida: "Oh, Oh, Oh, corinthiano maloquero e sofredô!".

O corinthiano não só se identifica com o povo, ele se assume como tal, como povo sofredor ${ }^{17}$. É mais uma lição, mais uma metáfora do futebol. Apesar de toda a carga justificadora das condiçóes de inferioridade do povo brasileiro (como prefere Darcy Ribeiro, elementos de cultura espúria), surge um time de futebol representativo da sua identidade e que assume, sem vergonha, a condição de povo.

A diferença é que, neste campo, o povo eventualmente vence. Vence com o time que "empurra" para a frente com sua torcida, com sua garra, com sua paixão.

\section{OS GAVIÕES}

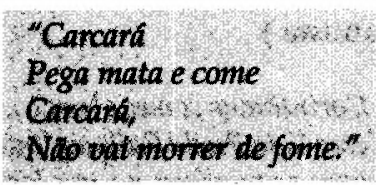

(Carcará. Música e letra de João do Vale.)

As torcidas organizadas são um fenômeno recente "e o surgimento das primeiras data do fim da década de 60 e começo de 70 . Constituem formas mais impessoalizadas e burocráticas de organização, estruturadas em moldes estatutários com presidente eleito para determinado período, conselho deliberativo e sócios, estabelecendo-se como instituiçōes privadas sem fins lucrativos ${ }^{18}$. O Grêmio Gaviōes da Fiel nasceu em 1969 e sua criação foi fruto de um movimento singular.

Segundo seu presidente, Jamelão, "foi na época do senhor Wadih Helou", seu Wadih Helou é o inimigo número 1 nosso, entende. Porque na época ele 
contratava capanga para batê em nós (...). Por que ele queria o quê? Ele queria que nós chegássemos no estádio, gritasse Corinthians, tando bem, tando ruim, de qualquer jeito. Ele queria comprar nós, né. Ofereceram para nós a sede, entende, bandeira, instrumentos. Falaram: Oh! vocês vão ser uma torcida uniformizada do Corinthians, só que vocês vão ter que: vocês nunca vão poder protestar, vocês vão ter que engolir. E esse grupo não aceitou. Então ele ia lá, contratava capanga que rasgava as bandeiras, quebrava os instrumentos (...), batia nos caras. Teve um jogo que eles acabaram com nós, né, deram porrada e tal. No jogo seguinte nós levamos uma faixa que dizia: "Os Gaviōes nunca acabarão". Dai para frente é este monstro que você está vendo. (...) Nasceu para quê? Nasceu para fiscalizar o Corinthians".

E o Grêmio certamente cresceu. Cinqüenta mil associados, vinte mil contribuições mensais (no valor de $R \$ 10,00$ ), venda de camisetas, bottons, adesivos etc., dois bares, uma quadra, um barracão, sete diretores, doze departamentos (Bandeira e Estádio, Bar e Lanchonete, Esportes, Social, Corinthians, Jurídico, Almoxarifado, Carnaval, Assessoria de Imprensa, Cultura, Patrimônio e Reformas e Bens) e onze funcionários. Esta é a principal parte da estrutura do Grêmio Gaviōes da Fiel ${ }^{20}$.

Os corpo de funcionários compreende contadora, telefonista, dois funcionários do bar, dois zeladores, dois técnicos em informática (CPD) e três relações públicas (para responder às 20 cartas diárias). Nenhum diretor ou presidente é remunerado. Os departamentos são formados por comissóes (de três a dez pessoas) de torcedores, participação também não-remunerada. Há ainda uma outra comissão, responsável pela gestão do carnaval (a administração e a contabilidade do carnaval são separadas daquelas da torcida).

O órgão máximo de decisão é o conselho deliberativo, formado por 40 membros, metade dos quais com mandato vitalício, e outra metade com mandato bianual. Pelo conselho deliberativo passam as mais importantes decisões do Grêmio como, por exemplo, sua participação no carnaval e a eleição do presidente e diretoria.

O momento de criação do Gaviōes da Fiel é bastante representativo da personalidade e da cultura hoje presente em seu interior ${ }^{21}$. O grêmio nasceu em 1969, num delicado momento político do país, por torcedores que tinham sido alijados de participação dentro do clube, numa fase de mudanças no futebol brasileiro. Este havia crescido, profissionalizadose, e os clubes estavam se estruturando burocraticamente, fazendo gerar uma elite de dirigentes. Desse processo foram alijadas camadas significativas de torcedores. No Corinthians, uma diretoria mais autoritária, respaldada pelo momento político nacional, acabou mostrando a contradição entre a estrutura administrativa do clube e a paixão corinthiana (time do povo, sem preconceito de cor etc.). Neste momento alguns torcedores criaram uma organização que respaldasse as suas reivindicações à diretoria do clube, cujo time não ganhava título havia muito tempo.

O Gavióes da Fiel nasceu como um sindicato, reclamando por participação e democracia: o sindicato da paixão corinthiana. A sua característica inicial era reivindicatória, evoluindo depois para se tornar um importante espaço de convívio e lazer entre seus associados. Acrescente-se a isso o fato de esse convívio ser potencializado por uma identidade comum: "todos são corinthianos". Numa cidade onde as alternativas de lazer, para determinada camada da população, são bastante limitadas, o grêmio prosperou. E prosperou a ponto de reivindicar a participação no carnaval. Conta seu presidente que "era bloco, não era nem escola de samba, eles (os integrantes do bloco) resolveram fazer bloco de rua, tirar barato, como é uma família né, todo mundo se encontrava. Ai resolveram montar um bloco (..), eles começaram levando assim na brincadeira e o negócio foi forte, começou a dar retorno, o pessoal começou a ir. Em treze vezes que os Gaviöes participaram
20. "Gaviões da Fiel" é também uma marca registrada.

21. 0 nome Gaviões nasceu, segundo seus diretores, porque 0 gavião é uma ave guerreira, astuta, com garra, que não tem medo de enfrentar seus inimigos. 
no desfile de bloco ganhou doze. (...). Fomos para o primeiro grupo, direto, porque fomos doze vezes campeã (...). Tudo que a gente entra a gente gosta de ganhar, de estourar, de ser o primeiro. É dificil a gente năo vencer, só se tiver uña trapaça".

A partir desse início vencedor nos blocos carnavalescos, a torcida Gaviōes da Fiel foi convidada, pela liga das escolas de samba, a participar do desfile do primeiro grupo. Segundo Pancho, diretor do Gavióes, " $a$ liga das escolas de samba falou: Oh! não tá tendo mais graça, infelizmente só vocês que tāo ganhando. Praticamente a gente foi obrigado a subir para o primeiro grupo, não era nossa idéia a princípio (...). Isto foi em 1988 ou 1989 (...). Ficamos em segundo no primeiro ano. Ai fomos para o grupo especial, isto em 89. Como foi o primeiro ano nosso no grupo especial (...) não deu cerfo, aí caímos para o grupo 1 de novo. No ano seguinte a gente batalhou, fomos campeâo do grupo 1, subimos de novo: fomos oitavo lugar, quinto lugar, segundo e agora. campeño".

Foi assim que o Gaviāo voou, ganhou personalidade própria, uma cultura definida, o que se comprova pelo grande número de torcedores com a camisa do grêmio nos jogos do Corinthians. É como se o sentimento de povo, de povo sofrido, próprio do espírito do corinthiano, tivesse absorvido outro elemento: o carcará guerreiro. A torcida ganhou uma simbologia própria, que tende a se incorporar na "marca corinthiana".

O grêmio foi gerado por uma disfunção capitalista e buroczática do futebol, pois foi criado por reação a um modelo burocrático de gestão, e possui características que o tornam uma organizaçāo singular:

- não tem um produto definido (como uma empresa);

- năo é apenas reivindicativa (como um sindicato);

- não "produz" lazer (o lazer está no campo de futebol, produzido pelos clubes, é só comprar o ingresso).

Além disso, tem, nos seus objetivos, o papel de denunciar o utilitarismo, pois trabalha com a emoção, com a paixăo pelo futebol - reflexos de identidades sociais.

Essa singularidade expresșa em sua estrutura organizacional pode ser analisada por componentes de sua cultura ou por aspectos norteadores da organização que se manifestam culturalmente. Nesse contexto, aplica-se a definição de cultura de DaMatta"22: "Porque, para mim, a palavra cultura exprime precisamente um estilo, um modo e um jeito, repito, de fazer as coisas".

Assim, a análise do Grêmio Gaviōes da Fiel, a seguix, terá como parâmetro metodológico a comparação direta com aspectos da cultura brasileira citados por autores clássicos da área, portanto, sem um compromisso maior com qualquer modelo formal de análise cultural proposto pela Teoria das Organizaçóes.

\section{ALGUNS ASPECTOS DA VIOLÊNCIA NO FUTEBOL}

"Deus me fez um card fraco, desdentido e feío

Pele e osiso simplesmente, quil'se sem recheio Mas se alguém me desafia $e$ bota a müe no meio Dou pernada a três por quatro e nem me despenteio Que êt já tô de saco cheio Deus me deu mão de 


\section{pelúcía prá fazer caricián \\ Déus mo deu muitaś \\ saudades e huita preguieg \\ Deus me deuperna comprida emuita malicia \\ Prá correr atrás de boláe \\ fugir da polícia \\ Um dia ainda sou notícia."}

(Partido Alto. Música e letra de Chico Buarque de.Holanda.)

Antes de iniciar a análise organizacional, abordemos rapidamente a questăo da violência nos campos de futebol ${ }^{23}$. Para tratar desse tema (sem a mínima pretensăo de esgotar o assunto), é necessário avaliar dois aspectos envolvidos: primeiro, o quê leva um indivíduo a se tornar violento (uma violência aparentemente motivada pelo futebol). Segundo, devese perguntar se as organizações que atuam nos eventos futebolísticos, em particular a torcida Gaviōes da Fiel ${ }^{24}$, estimulam a violência.

A paixāo é invariavelmente a justificativa da maioria dos torcedores envolvidos em ocorrências violentas no futcbol: a paixão pelo time, pela camisa que leva a laços de identidade, ao sonho coletivo, a ideais supostamente compartilhados por todos os torcedores daquele time.

O rompimento da estrutura familiar na sociedade industrial (ou pelo capitalismo) fez com que o homem das grandes cidades buscasse novas formas de identidade e, como visto anteriormente, que o futebol se tornasse um veículo que referencia essa identidade. Aliado a este e outros citados laços de identidade, o Brasil tem un componente de sua cultura, segundo DaMatta ${ }^{25}$, extremamente marcante: é a idéia de casa, ou seja, onde somos membros de uma mesma familia e de um grupo fechado bem definido. Este conceito pode ser incorporado à identidade futebolística. Em maior ou menor grau, os integrantes de uma mesma torcida sentem certos laços que os unem, tal qual uma família ${ }^{26}$, seja ela corinthiana, palmeirense etc.

Ora, uma discussāo sobre as proezas ou defeitos de um time de futebol, que leve a uma ofensa a este, pode parecer un desrespeito ao sentimento de coletividade e de familia. Pode parecer, a um torcedor mais fanático, uma provocação (o mesmo que ofender a mãe), uma delíberada tentativa de rompê-lo com a sua coletividade ou mesmo com o sonho coletivo representado pelo time. A violência seria uma tentativa de defesa contra a possibilidade desse rompimento.

Contudo, nāo é somente esse tipo de violência que ocorre nos espetáculos de futebol. Freqüentemente os noticiários narram fatos relativos a bandos de torcedores, na maioria jovens, que depredam ônibus, metrố, bens públicos e privados e eventualmente alguma vítima indefesa. "Qualquer aglomeração de indivíduos, na maioria jovens entre 14 e 20 anos formada de grupos involuntários de torcedores adversários na cidade é motivo para se eclodirem os enfrentamentos. A rivalidade é a resposta de imediato, aparentemente anárquica, sem motivaçöes além da emoçāo do instante da transgressão regida por una solidariedade 'mecânica', cuja identidade e coesāo muitas vezes são flácidas e circunstanciais" ${ }^{27}$.

Muitos creditam esse tipo de violência ao advento das torcidas uniformizadas e os argumentos as apontam como incentivadoras desse comportamento. Tal argumento é, entretanto, bastante simplista e não busca a causa do problema. Toledo apresenta um estudo que compara as torcidas organizadas do Brasil aos hooligan (torcida inglesa, de notória violência), concluindo que elas, pelo menos institucionalmente, não estimulam a violência, e até a condenam ${ }^{28}$. Não se trata, portanto, de uma violência institucionalizada ou estrutural ${ }^{29}$ e seu caráter é bastante dife renciado daquela do futebol inglês.
23. Este capítulo faz-se necessário em razão das crescentes ocorrênicias envolvendo torcedores e torcidas nos campos de futebol. Há uma corrente que responsabiliza diretamente as torcidas uniformizadas pela violềncia, mas esta argumentaçāo, sem a devida reflexão, pode contradizer as conclusōes do estudo feito junto ao Grêmio Gaviões da Fiel.

24. Como não conhecemos outras torcidas organizadas, não queremos generalizar o que pôde ser observado na dos Gaviões da Fiel, mesmo porque, segundo seu próprio presidente, esta è uma das poucas torcidas em que existe alternância de poder e muita preocupação com seu reconhecimento social.

25. DaMATTA, R. O que fazo Brasil... Op. cil.

26. Ver-se-á a seguir que os membros dos Gaviōes da Fiel tratam os corinthianos como "familia corinthiana" e a quadra da organização como "casa".

27. TOLEDO, L. H. Transgressão e violência entre... Op. cit., p. 93101.

28. Os dirigentes dos Gaviōes da Fiel são categóricos ao afirmar que se um torcedor ế flagrado cometendo um ato de violência "grave" (pixar ônibus, soltar bomba etc.) é sumariamente expulso do quadro de associados.

29. Os dirigentes dos Gaviões da Fiel, pelo menos formalmente, nas entrevistas realizadas, sāo insistentes na condenação da violência pelos associados. Argumentam que tentam controlar seus sócios reprimindo-os (expulsão, suspensão), usando $\mathrm{pa-}$ lavras de controle (lealdade, humildade e procedimento) e fazendo palestras disciplinadoras (o sócio é obrigado a freqüentar duas reuniōes para adquirir a camisa da organização). 
É fato, porém, que certas atitudes de torcidas uniformizadas podem demonstrar o contrário do que pregam seus dirigentes ${ }^{30}$. Muitos cronistas esportivos afirmam que essas torcidas, apesar de isoladamente nāo provocarem a violência, a potencializam. Segundo eles, esse tipo de estímulo à violência pode ser percebido nos gritos de guerra e em manifestaçöes de torcedores, como no testemunho de um membro da torcida Gavióes da Fiel: "Se a gente fica sabendo que a Mancha (torcida do Palmeiras) está ali, oh, arregaçando um corinthiano, ai é o ato de reação, é como um. Lutador de faixa preta de judô ou caratê, ele nāo mexe comn ninguém, ele fica na dele, mas vai você mexer com ele!".

A melhor explicação para esse tipo de comportamento foi dada por Toledo 31 : "Para além da gratuidade e obviedade das agressóes disparadas das arquibancadas, como pensam alguns, os duelos verbais travados pelos torcedores devem ser compreen-

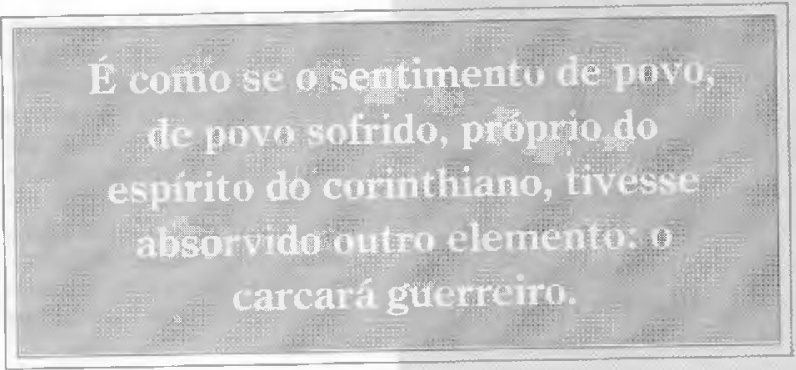
didos dentro de uma trama ritual de significaçôes simbólicas, filtrada e codificada em músicas e versos, a partir de temas e pares de oposição" encontrados dentro da própria sociedade, e que essas manifestaçôes no futebol colocam "em evidêntcia, sugerindo um confronto, as diferenciaçôes sociais entre as classes, a oposição e os papéis desempenhados e atribuidos aos sexos (futebol é para homem), as fissuras entre o público e o privado, as relaçōes de poder (tudo quanto é cartola é ladrāo)".

As torcidas uniformizadas, ainda segundo Toledo, possibilitariam marifestaçōes que refletem, como uma vitrine, elementos contidos na organizaçăo social brasileira. $\mathrm{O}$ autor ${ }^{32}$ ainda alerta para o fato de que "todos estes comportamentos expressivos observados, que ditam a conduta torcedora dentro do ritual futebolístico, quando extravasados dos limites do socialmente aceito ou mesmo aproximados às condutas que regulam a esfera cotidiana, per-

30. Por exemplo, um grito de guerra famoso da Torcida Independente do São Paulo, incorporado ao universo futebolístico, fala, do começo ao fim, em "dar porrada" (vou dar porrada eu vou), e que ninguém vai segurar 0 torcedor (nem a Polícia Mili(ar).

31. TOLEDO, L. H. Por que xingam os torcedores de futebol? Cadernos de Camoo. São Paulo, n. 3, p. 20-8, 1993.

\section{Idem, ibidem.}

33. Este comportamento também é condenado pela direção do Grêmio Gaviōes da Fiel, como poderá ser observado mais adiante no ritual por que passa 0 torcedor quando se filia a entidade (rito de iniciação). Outra atikude efetiva dessa torcida no sentido da contenção da violência é observada num sistema de controle informal, amplamente difundido, que existe dentro da entidade e foi resumido nas palavras "humildade, leaidade e procedimento". Estas passagens serāo apresentadas no próximo capítulo.

34. TOLEDO, L. H. Transgressão e violência entre... 0p. cit., p. 93106. dem o caráter de permissividade e certa tolerância, passando a adquirir características nitidamente transgressoras, de baderna, caos e maior possibilidade de conflitos" 33 .

Esta última forma de comportamento, que extravasa o limite do tolerável, pode ser creditada também a certas características da sociedade brasileira, que encontra um campo fértil para se manifestar no futebol, dado o volume de pessoas que dele participam. É o tipo de violência que relatou um ex-presidente do conselho deliberativo do Gaviōes da Fiel, Clay: "A violência começa no ônibus que vai para o estádio, no ingresso que você paga, na atitude da própria polícia (...). A Gaviöes hoje têm 50 mil sócios, o caminho que este pessoal faz é da periferia, entâo, o cara tem violência em casa, tem violência no trabalho, violência em tudo quanto é lugar, você acha que ele não vai ter violência num trajeto para o futebol? O futebol não é a parte da sociedade".

Há inúmeras formas de reação à violência cotidiana a que está sujeita a sociedade brasileira, e o futebol e as torcidas organizadas certamente também são permeáveis nesse sentido. Por outro lado, dado o público predominantemente jovem das torcidas uniformizadas, conforme pondera Taussig, citado por Toledo", "ressalta-se a existência de um crescente processo de banalização da violência e da transgressão observado nos grandes centros urbanos brasileiros. Processo que recoloca o fenômeno da violência como espetáculo performático e de 'massa' (programas radiofônicos e televisivos cotidianamente mostram o fenômenn da violência como sendo 'a verdade nas ruas como ela é' em um'show de noticias') (...) em que a instável interação de verdade e ilusão (ficçāo) torna-se uma força social de tremendas dimensöes (...)". Uma argumentação que também responsabilizaria a midia por uma parcela dessa violência. 
Nesse aspecto, bastaria um bando de adolescentes querendo mostrar suas habilidades marciais e de transgressão (ou, como disse um dirigente do Gaviões, "querendo ser Van Dame" - ator que só faz filmes violentos) para eclodirem cenas de violência. César ${ }^{35}$ afirma que "o comportamento dos torcedores voluntários, como pude comprovar e comparar nos outros jogos, é muito mais violento e liberto que o dos torcedores componentes das torcidas organizadas" 36 .

Coloque todos esses componentes, em maior ou menor grau, num caldeirão, tempere com um pouco de crise econômica - que aprofunda a péssima distribuição de renda do país - , e certamente se terá um prato com o gosto amargo da violência no futebol do Brasil.

\section{A ORGANIZAÇÃO CORDIAL}

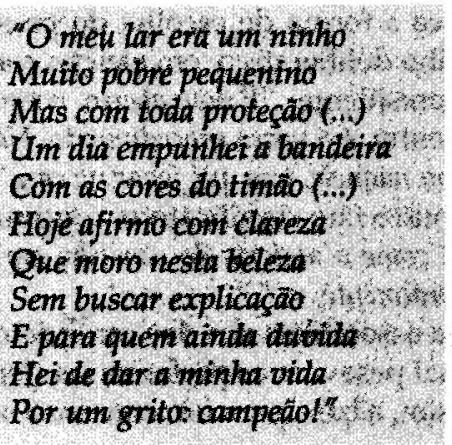

(Poesia de Pixuca em homenagem à Escola de Samba Gaviōes da Fiel, publicada no jornal Os Gaviöes.)

São visíveis, óbvias, as características da cultura brasileira dentro da torcida uniformizada Gaviōes da Fiel. Contudo, uma sobressai: a de que é uma organização que nasceu para possibilitar e manter laços de identidade, de afeto e de paixão. Não é casual sua inserção no universo futebolístico. $O$ torcedor, estimulado a compartilhar novas bases emocionais e de solidariedade que substituíssem as pequenas comunidades e laços de parentesco, descobriu no futebol, devido às suas características singulares, terreno propício de manifestação dessa carência. O Grêmio Gaviões da Fiel, em meio a uma sociedade de organizações impessoais, ofereceu ao torcedor o veículo de expressão e de vivência de certo tipo de emoção, permitindo-lhe adquirir uma identidade social.

O Grêmio Gaviões da Fiel nasceu em conseqüência de um esgotamento da capacidade do futebol, enquanto espetáculo, em estimular laços de identidade e solidariedade. Despontou em reação a um modelo de organização do futebol oficial, excludente, impessoal, portanto, incapaz de propiciar ao torcedor aqueles laços fundamentais, de paixão inclusive (ou de cordialidade, como prefere Sérgio Buarque de Holanda).

O próprio objetivo da organização, "torcer" pelo Corinthians, já denuncia esses elementos de cordialidade. $\mathrm{O}$ amor pelo Corinthians, dizem os torcedores, é de difícil explicação, é antes de tudo um sentimento que brota do fundo da alma, do coração. O Grêmio Gaviōes da Fiel cria as condições de manifestação desse sentimento e absorve, como organização dotada de "personalidade" e cultura, as características de emoção de seus membros ${ }^{37}$.
35. CÉSAR, B. Tadeu. Os Gaviōes da Fiel e a Águia do Capitalismo. Campinas: UNICAMP 1981, 178 p. (Dissertação apresentada ao Programa de PósGraduação em Antropologia Social).

36. Ressalta-se que neste caso ao contrário dos argumentos predominantes, as torcidas uniformizadas têm, ou podem ter. papel efetivo de controle da vioIência manisfestada por estes grupos caóticos. Neste caso seria mais eficaz se se utilizassem estas organizações para coibir e educar estes jovens para a nãoviolência do que simplesmente proibi-las, perdendo um real canal de interlocução.

37. Esta é a definição de cordialidade de HOLANDA, Sérgio Buarque de. Raízes do Brasil. 26. ed. São Paulo: Companhia da Letras, 1995. $147 \mathrm{p}$. 
38. CANDIDO, A. 0 significado de raízes do Brasil: texto introdutório. In: Raizes do Brasil. 26 ed. São Paulo: Companhia das Letras, 1995.

39. 0 presidente dos Gaviões afirmou ainda que esse procedimento é uma prática histórica.

40. Leal à "família" Gaviões, aos laços de identidade coletiva.

41. Apesar de se tratar de marca patenteada, camisas e objetos com a marca Gaviões da Fiel são vendidos livremente por lojas e camelôs. Esse fato faz os dirigentes dos Gaviões da Fiel afirmarem que muito dos atos de violência creditados a associados dos Gaviões sejam feitos por pessoas com essas camisas "falsas".

42. 0 culto à camisa (que é diferente do uniforme do Corinthians), demonstrado neste ritual de iniciação, já denuncia, por si só, um mito revelador dos laços de identidade.
"O 'homem cordial' não pressupöe bondade, mas somente o predomínio dos comportamentos de aparência afetiva, inclusive nas manifestações externas, não necessariamente sinceras nem profundas, que se opõem aos ritualismos da polidez. O 'homem cordial' é visceralmente inadequado às relações impessoais que decorrem da posição e da função do individuo, e não da sua marca pessoal e familiar, das afinidades nascidas na intimidade dos grupos primários" ${ }^{\prime 38}$.

O Grêmio Gaviões da Fiel propõe uma nova forma de convivência entre seus membros com base nas relações de identidade e afeto que o geraram. Nele, as relações pessoais não são apenas importantes, são sua condição de existência. Obviamente, numa organização que tem como objetivo a manifestação da paixão, a impessoalidade burocrática não poderia ser a base de sua estrutura administrativa.

Esta lógica de fundo emotivo transparece em toda a estrutura do grêmio, mas é particularmente significativa a forma de escolha do presidente. O presidente é eleito pelo conselho deliberativo, em eleição com voto aberto, como relata Jamelão, seu presidente: "É voto aberto, porque aqui a gente tem que jogar na cara um do outro, é o nosso procedimento. Não tem que ficar com medo se vai votar nesse ou naquele, tem que jogar na cara".

$\mathrm{Na}$ última eleição, ainda houve um outro fato significativo, continua o presidente: "Foram dois candidatos, aí como a maioria do conselho era o Jamelão, o outro candidato abriu mão, naturalmente, né" 39.

$\mathrm{Na}$ última eleição, previamente à sua assembléia um dos candidatos abriu mão em favor daquele sobre o qual pesavam as preferências (tem que "jogar na cara"), estabelecendo, assim, a base para um consenso interno.

Mesmo o relacionamento entre os membros do conselho, nas reuniões, é denunciadora da paixão que permeia toda a organização. Comenta o ex-presidente do conselho, Clay: "A gente discute calorosamente. Há uma certa discussão fervorosa mesmo, de gritos e tal, mas, saiu daqui para fora, todo mundo é Gavião. Acabou a reunião do conselho a gente desce e todo mundo é Gavião, vamos tomar cerveja, comer pizza, zuá, fazer o que tiver que fazer. A gente não tem aqui uma discórdia homérica".

Existem também, na quadra da organização, pintadas numa parede, de forma muito visível, as três expressões já citadas aqui, utilizadas como base do controle sobre seus associados: lealdade, humildade e procedimento. "Isto é uma frase de um sócio nosso, que hoje é falecido, que Deus o tenha em bom lugar," continua o ex-presidente do Conselho Deliberativo, "lealdade: você tem que ser leal ao Corinthians, aos Gavióes". $\mathrm{Hu}$ mildade: você tem que ser humilde, não pode, porque você hoje faz parte de uma torcida que é considerada talvez a maior do mundo, não ser humilde, você tem de tratar todo mundo igual. Eo procedimento é um procedimento de que quando você põe a camisa dos Gaviōes, você está representando uma nação, você está representando não só você e a sua familia: você está representando a família Gaviōes da Fiel".

Essas palavras, resumidas na sigla LHP, são insistentemente repetidas para toda a organização e é a principal forma de controle sobre os associados (existem ainda, é claro, mecanismos de suspensão e expulsão). Ao se associar ao Gaviões, o torcedor, antes de receber a camisa ${ }^{41}$, passa por duas reuniōes, afirma Jamelão, seu presidente que "quando ele recebe a carteirinha, assiste a primeira que é prá saber a história dos Gaviões e a segunda ele vai assistir para ver a conduta que ele vai levar nos Gaviões. Dentro desse prazo ele demora um mês para adquirir a camisa ${ }^{42}$ dos Gaviōes, para que, para a gente pegar quem tá a fim de participar, às vezes o cara entra só para ter a camisa e dá trabalho".

Mesmo os meios de controle mais formais, como a suspensão e a expulsão do associado, é permeada por uma lógica de fundo emotivo. $\mathrm{O}$ 
presidente tem o poder de expulsar o membro que "ñāo tem o procedimento de um Gaviōes". Não existe ưma norma escrita sobre o que vem a ser o "procedimento de um Gavião"; ao que parece, este é um conceito entendido e incorporado intuitivamente por todos. Caso seja um membro mais velho ou um conselheiro, só o conselho pode expulsar.

A paixão, presente em toda estrutura do Gaviōes, também é responsável por comportamentos não tão amistosos. Algumas formas de relacionamento revelam doses de intolerância, nāo só com a torcida do time adversário, já que esta não comunga da mesma identidade, da mesma paixăo, e eventualmente pode destruir, frustrar um sonho de vitória (o ódio é tão cordial quanto o amor), como também há manifestações de intolerância com todos aqueles que não apresentam o perfil dessa identidade como, por exemplo, os homossexuais. Conforme categoricamente afirmou um diretor do grêmio, um dos comportamentos passiveis de expulsão é o homossexualismo. Mesmo sob este aspecto é visivel a influência da cultura brasileira: trata-se da "defesa moral" da casa ou família pelo homem brasilei$\mathrm{no}^{43}$.

Este procedimento leva a organização a criar mecanismos de distinçāo semelhantes àqueles que determinam diferenças entre a casa e a rua: É um ambiente familiar, aqui você

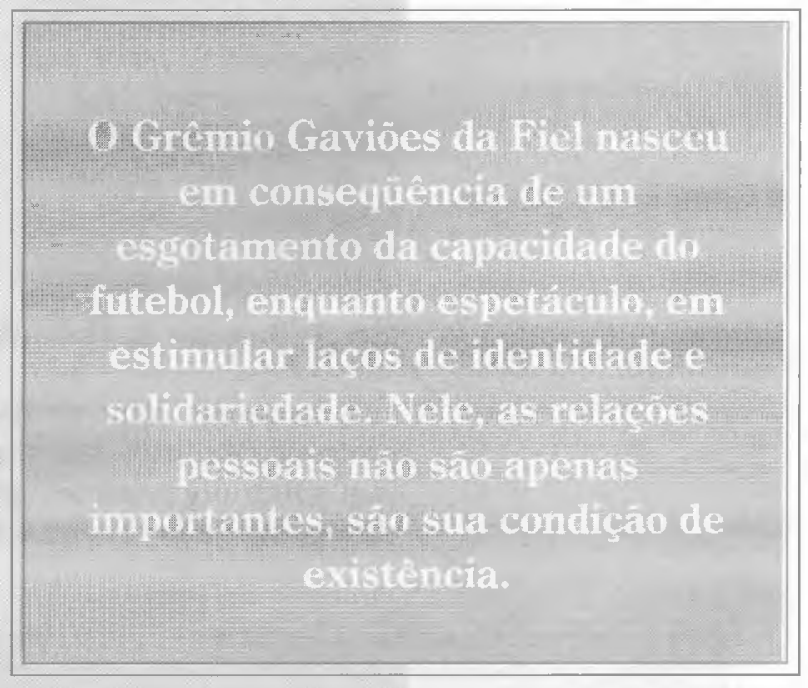
não vê neguinho querer ficar te medindo, ou querer te roubar, querer passar droga, porque quem a gente encontrar é eliminado sumariamente. (...) Tem controle porque a gente tem que botar respeito (...) Dentro da quadra é expressamente proibido o uso de drogas, do portão para fora ai qualquer um faz o que quiser (...) É a lei nossa aqui dentro (...) O cara vai vir aqui curtir os Gaviões, ele vai curtir os Gaviōes. Näo vai poder fazer coisa errada aqui dentro, como em qualquer outro lugar (...) e se ele nāo aceitar isto, então ele não é bern vindo aqui dentro", afirma seu presidente.

A grande quantidade de mulheres que participam da vida coletiva da entidade ${ }^{44}$ é outro fato chama a atenção do observador. É verdade que aqui as mulheres, tal qual na maioria das organizaçóes brasileiras, nāo exercem papel de liderança, mas já é um grande avanço a sua participação no mundo do futebol, notadamente masculino ${ }^{45}$. Clay, ex-presidente do Conselho Deliberativo, relata: "Esta festa que vai ter, festa junina, são elas que estāo elaborando, nas nossas rodas de samba elas que recepcionam, elas que vāo ver as mesas. São elas que bolam tudo, os conjuntos que vão trazer. A gente tinha time de futebol feminino, temos time de vôlei, time de basquete. As mulheres participam muito, dão porrada quando precisam, vão para a arquibancada. Elas querem estar participando".

No carnaval ou nas "festas" das arquibancadas, tem-se mais um forte componente da cultura brasileira. Não foi por acaso, como podem sugerir alguns de seus dirigentes, que o grêmio virou escola de samba, tendo, nestes dois momentos, os mesmos integrantes. Esses associados viram, no desfile das escolas de samba, mais uma oportunidade de demonstrar sua paixão. A passarela foi um palco perfeito para o casamento de uma paixão (corinthiana) com um ritual que, tal como sugere o futebol, inverte a lógica altamente hierarquizada da sociedade brasileira ${ }^{46}$.

Finalmente, outra característica da cultura brasileira a ser observada no Grêmio Gaviōes da Fiel é o papel da intermediação, pelo fato de que

43. Ver a Casa e a Rua em DaMATTA, R. O que faz o Brasil... Op. cit.

44. Tanto no campo como na sede social observei várias muIheres (em torno de 10 a 20\%) que participam da vida cotidiana do grêmio. Nas festas e nos ensaios da escola de samba, um membro chegou a afirmar que a quadra do Gaviōes parece o "litoral norte" - balneário paulista famoso pelo número e beleza das mulheres.

45. 0 Corintlianıs lem tradiçäu de torcedoras femininas. 0 torcedor símbolo do Corinthians. por muito tempo, foi uma muIher (Eliza).

46. Ver DaMATTA, R. O que faz o Brasil... Op. cit. 
por meio dele a paixáo corinthiana consegue se manifestar dentro do futebol profissional, diminuindo o abismo criado por uma instituiçāo excludente. O grêmio é inclusive um canal de comunicaçăo entre o torcedor e seus ídolos (recebe entre 20 e 30 cartas de torcedores diariamente, boa parte dirigida aos jogadores).

\section{CONCLUSŌES}

"Já se đissé, numa expressīo feliz, quéa contrilbuição brasileira. para a civilização será de cordialidade - daremos aos mundo o homean cordial."

(Sérgio Buarque de Holanda, em O homem cordial.)

É fascinante como numa sociedade permeada por relaçōes capitalistas táo profundas e consolidadas, que tendem a homogeneizar todas as relaçōes, possam surgir organizaçôes que denunciem o utilitarismo como valor e estejam carregadas de forte conteúdo da cultura nacional.

O Grêmio Gaviões da Fiel está inserido nesse contexto, sobre o qual muito pouco se

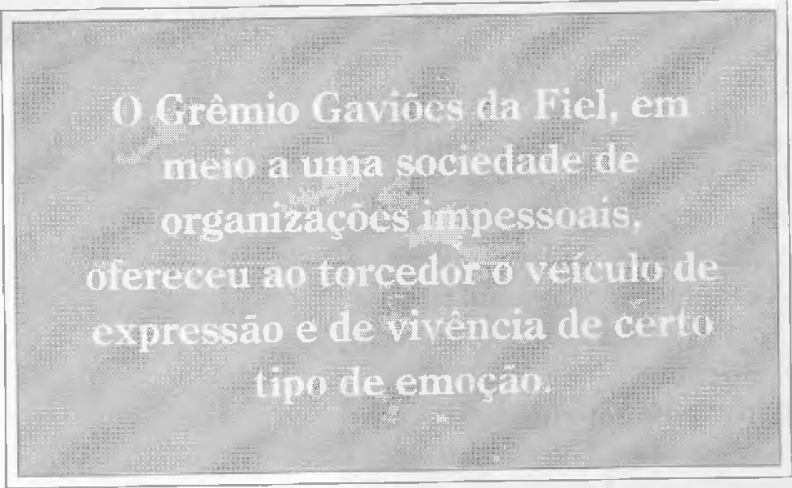
debruça a intelectualidade brasileira. Com poucos recursos administrativos, baixo formalismo nas relaçōes, estruturado no trabalho voluntário e na participaçāo, com uma lógica política emotiva, o Grêmio Gaviōes da Fiel consolidou-se como aglutinador de um movimento que já é cultural - interfere no carnaval - , capaz de significativas doses de mobilizaçāo popular.

É também interessante, usando o exemplo do sucesso do modelo japonês de administraçāo (calcado na cultura de origem), que em muitos dos aspectos da organizaçăo $\mathrm{Ga}-$ viões da Fiel, respeitadas suas particularidades, possa estar a base para criaçāo de um modelo administrativo de carácter nacional, com a incorporaçāo de inúmeras e criativas facetas da cultura brasileira.

Muitas características observadas no Gaviōes da Fiel, principalmente a "lógica de fundo emotivo", podem ser observadas em outras organizaçōes brasileiras, particularmente em pequenas e médias empresas familiares.

Ao Gavióes da Fiel cabe um cuidado: criar formas de organizaçāo capazes de manter sua estrutura transparente e permeável à participaçāo dos associados, de modo a não incorrer no mesmo erro do Sport Club Corinthians Paulista, que forçou a criação do próprio grêmio, como escreveu um de seus associados: "A política e a sede de poder parecem estar suplantando os ideais dos Gaviōes. Não há mais discussōes entre quatro paredes, não se falam as coisas mais cara a cara, grupos se isolam e formam suas próprias lideranças. Espero que todos nós tenhamos como obje-

47. Paulo Sérgio S. Corrêa, 27 anos, formado em Administração de Empresas e coordenador de estatística da indústria Votorantim. Texto extraido do jornal OS Gaviōes, Sāo Paulo, mar. 1995, ano VIII, ก. 38 . 